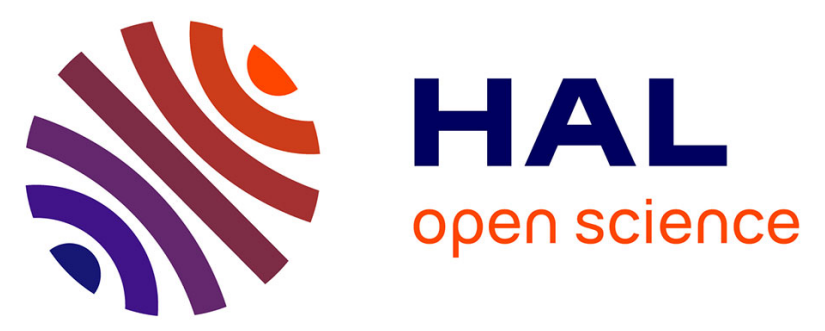

\title{
Characterising the interior structures and atmospheres of multiplanetary systems.
}

Lorena Acuña, Magali Deleuil, Olivier Mousis, Théo A. López, Thierry Morel, Alexandre Santerne, Emmanuel Marcq

\section{- To cite this version:}

Lorena Acuña, Magali Deleuil, Olivier Mousis, Théo A. López, Thierry Morel, et al.. Characterising the interior structures and atmospheres of multiplanetary systems.. European Planetary Science Congress. EPSC 2021, Sep 2021, Virtual Meeting, France. pp.306-322, 10.5194/epsc2021-44 . insu03313865

\section{HAL Id: insu-03313865 \\ https://hal-insu.archives-ouvertes.fr/insu-03313865}

Submitted on 4 Aug 2021

HAL is a multi-disciplinary open access archive for the deposit and dissemination of scientific research documents, whether they are published or not. The documents may come from teaching and research institutions in France or abroad, or from public or private research centers.
L'archive ouverte pluridisciplinaire HAL, est destinée au dépôt et à la diffusion de documents scientifiques de niveau recherche, publiés ou non, émanant des établissements d'enseignement et de recherche français ou étrangers, des laboratoires publics ou privés. 
EPSC Abstracts

\section{Characterising the interior structures and atmospheres of multiplanetary systems.}

Lorena Acuña ${ }^{1}$, Magali Deleuil ${ }^{1}$, Olivier Mousis ${ }^{1}$, Théo A. López ${ }^{1}$, Thierry Morel ${ }^{2}$, Alexandre Santerne ${ }^{1}$, and Emmanuel Marcq ${ }^{3}$

${ }^{1}$ Aix Marseille Univ, CNRS, CNES, LAM, Marseille, France. (Iorena.acuna@lam.fr)

${ }^{2}$ Space sciences, Technologies and Astrophysics Research (STAR) Institute, Université de Liège, Liège, Belgium

${ }^{3}$ LATMOS/CNRS/Sorbonne Université/UVSQ, Guyancourt, France

The increasing number of well characterised low-mass planets, combined with the valuable informations from stellar and planetary spectroscopy, opens the way to the modeling of planetary structures and compositions, which can be obtained with theoretical and numerical works. This approach gives a valuable insight to understand the formation of planetary systems in the low-mass range. We present a $1 \mathrm{D}$ planetary model where the interior is coupled with the atmosphere in radiative-convective equilibirum within a Bayesian retrieval scheme. In addition to a Fe core and a silicate mantle, we take into account water in all its possible phases, including steam and supercritical phases, which is necessary for systems with a wide range of stellar irradiations.

Our interior-atmosphere model calculates the compositional and atmospheric parameters, such as Fe and water content, surface pressures, scale heights and albedos. We analyse the multiplanetary systems K2-138 and TRAPPIST-1, which present six low-mass planets with different densities and irradiations. From the individual composition of their planets, we derive a similar trend for both systems: a global increase on the water content with increasing distance from the star in the inner region of the systems, while the planets in the outer region present a constant water mass fraction. This trend reveals the possible effects of migration, formation location and atmospheric mass loss during their formation history. 